\title{
KAJIAN USAHATANI PADI DI LAHAN PASANG SURUT DAN PENERAPAN TEKNOLOGI TEPAT GUNA DI DESA BANYUURIP KECAMATAN TANJUNG LAGO KABUPATEN BANYUASIN
}

\author{
${ }^{1}$ Agoes Thony Ak, ${ }^{2}$ Endah Novitarini \\ ${ }^{1,2}$ Department of Agribusiness, Faculty of Agriculture, Sjakhyakirti University \\ Palembang, 30662, South Sumatra, Indonesia \\ Correspoding Author email : agoesthonyak@gmail.com
}

\begin{abstract}
Abstrak
Indonesia saat ini tidak lagi punya banyak pilihan dalam rangka mewujudkan ketahanan pangan nasional selain memanfaatkan lahan-lahan suboptimal yang masih tersedia dan memungkinkan untuk dikelola sebagai lahan produksi pangan, karena upaya peningkatan produktivitas sudah semakin sulit secara teknis agronomis dilakukan dan juga semakin tidak ekonomis untuk diusahakan. Namun demikian, perlu dipahami bahwa lahan-lahan yang tergolong pasang surut mempunyai beragam karakteristik dan potensinya. Oleh sebab itu, perlu diprioritaskan pada pengembangan teknologi yang secara teknis relevan untuk masing-masing karakteristik lahan pasang surut tersebut, secara ekonomis terjangkau oleh petani setempat, serta diharapkan juga selaras dengan preferensi dan sosio-kultural masyarakat setempat. Dua pendekatan yang dapat secara paralel dan interaktif dilakukan adalah [1] optimalisasi sifat fisik, kimia, dan (mikro)biologi tanah yang dibarengi dengan optimalisasi pengelolaan sumberdaya air agar efektif dan lebih efisien; dan [2] seleksi jenis komoditas yang sesuai dan pengembangan varietas yang adaptif secara spesifik untuk masing-masing karakteristik lahan suboptimal. Untuk mewujudkan keberlanjutan pengelolaan lahan suboptimal, maka semua upaya teknis dan teknologis yang dilakukan harus pula mempertimbangkan kemungkinan dampak ekologisnya, kesesuaian sosiokultural dengan masyarakat lokal, selain tentunya menguntungkan secara ekonomi bagi petani sebagai pelaku utamanya. Lahan pasang surut membutuhkan lebih banyak intervensi teknologi agar dapat dijadikan lahan pertanian yang produktif. Upaya ini selain mahal secara ekonomi, sering juga beresiko tinggi bagi lingkungan. Mudah untuk dipahami bahwa tidak seluruh bentang lahan pasang surutl dapat dan perlu dimanfaatkan untuk kepentingan ekonomi. Dengan demikian maka tidak semua jengkal lahan suboptimal harus digunakan sebagai lahan produksi; sebagian perlu tetap diperuntukan bagi kepentingan konservasi. Rata rata biaya produksi usahatani padi pasang surut di desa Banyu urip adalah Rp.15.880.907 perluas garapan permusim tanam. Rata rata pendapatan yang diterima oleh petani contoh sebesar Rp. 10.544.093,- dan penerimaan diperoleh sebesar Rp. 26.425.000,- luas garapan permusim tanam. Dan R/C usahatani padi sebesar 1,88. Artinya setiap Rp 1 yang di keluarkan petani untulk proses produksi maka petani mendapatkan keuntungan sebesar 1,66. hal ini menunjukkan bahwa usahatani padi di lahan pasang surut layak untuk di lanjutkan ataupun dapat member keuntungan kepada petani sebesar 1,88.
\end{abstract}

Kunci : lahan pasang surut, usahatani. Teknologi tepat guna 


\section{PENDAHULUAN}

\section{A. Latar Belakang}

Sebelum terjadinya krisis ekonomi dalam tahun 1997, kontribusi sector pertanian (tanaman pangan, perkebunan, peternakan, kehutanan dan perikanan) pada produk Domestik Regional Bruto (PDRB) di Sumatera Selatan tahun 1996 sebesar 20,18\% dan pada tahun 2000 sumabangannya agak menurun menjadi sebesar $16,7 \%$. Sektor ini merupakan penyumbang ketiga terhadap PDRB setelah pertambangan/penggalian dan industry pengolahan. Yang menarik selama krisis ekonomi menunjukan bahwa PDRB pertanian tetap tumbuh positif, kontribusi terhadap PDRB meningkat 9,47\% pada tahun 2000 sedangkan sector lain ada yang memiliki pertumbuhan negativ (BPS dan Bappeda Provinsi Sumatera Selatan, 2001).

Tidak heran jika pemerintah Daerah (Pemda) Sumatera Selatan menetapkan pertanian sebagai sektor unggulan pertama dalam pembangunan perekonomian daerah selain Perkebunan, Pertambangan, Pariwisata, Industri KecilMenengah dan Kerajinan Rakyat dan sector Kelautan (Bappeda Provinsi Sumatera Selatan, 2001).

Sektor pertanian berperan penting dalam penyediaan kecukupan pangan baik kuantitas maupun kualitas bagi seluruh penduduk yang terus meningkat jumlahnya. Disamping itu, sektor pertanian diarahkan untuk mampu menyumbangkan devisa bagi Negara serta memberikan lapangan kerja dan dukungan kuat terhadap pembangunan sector lain (Jhinghan, 1994 ; Ar-Riza, 2000). Salah satu andalan sector pertanian adalah sub sector tanaman pangan yang dikembangkan untuk meningkatkan produksi guna mencapai swasembada pangan pangan, memperbaiki kualitas gizi masyarakat melalui diversifikasi jenis pangan, meningkatkan pendapatan petani serta kesempatan berusaha.

Beras sampai saat ini masih tetap merupakan komoditas strategis secara ekonomi, social dan politik. Pada tahun 1998 konsusmsi beras di Indonesia telah mecapai $135 \mathrm{~kg} / \mathrm{kapita} / \mathrm{tahun}$ (Saragih, 1998). Kegoncangan produksi beras akan mengakibatkan mastyarakat gelisah, dan berpengaruh langsung terhadap kehidupan rumah tangga petani yang merupakan bagian terbesar dari penduduk Indonesia (Ar-Riza, 2000).

Kabupaten Banyuasin merupakan daerah yang mempunyai potensi areal pasang surut yang terluas di Sumatera Selatan, yakni dari luas tanam yang ada saat ini seluas 153.000 ha dari (362.000 ha yang sudah direklamasi), baru 5000 hektar yang telah dapat ditanami dua kali setahun yaitu dikawasan Delta Telang I (Dinas Pertanian dan Peternakan Banyuasin, 2005). Namun demikian pemanfaatannya belum optimal karena adanya berbagai kendala. Indikasi terlihat dari tingkat produksi yang masih rendah dan belum meningkatnya kesejahteraan petani pada umumnya.

Menurut Hendro (2003), umumnya petani tidak pernah menghitung atau menganalisa kegiatan usahataninya, akan tetapi dalam agribisnis petani harus berpikir untuk mencari keuntungan untuk dapat mengembangkan usahanya. Ada tiga hal yang mendasari analisis usahatani yaitu biaya produksi, pendapatan dan keuntungan. Keadaan petani di Desa Banyuurip Kecamatan Tanjung Lago Kabupaten Banyuasin yang melakukan usahatani padi umumnya belum mengadakan perhitungan-perhitungan terinci terhadap kegiatan usahataninya secara tertulis atau belum membuat perhitungan analisa usaha. Hal tersebut disebabkan keterbatasan pengetahuan dan kemampuan petani, sehingga berdampak terhadap peningkatan usahataninya. 
Berdasarkan uraian diatas maka penulis tertarik untuk melakukan penelitian yang berjudul Kajian usahatani padi (Oryza sativa) di di Desa Banyu urip Kecamatan Tanjung Lago Kabupaten Banyuasin Sumatera Selatan.

\section{B. Rumusan Masalah}

Dengan bertambahnya luas panen, luas tanam di lahan pasang surut diharapkan produksi yang tinggi dapat meningkatkan pendapatan petani, untuk itu petani perlu membuat suatu analisis usahatani sehingga dapat mengetahui apakah usahatani padi yang dilakukan oleh petani selama ini menguntungkan dan layak untuk dikembangkan,

Berdasarkan uraian diatas dapat dirumuskn masalah sebagai berikut;

1. Bagaimanakah strategi Teknologi tapat guna yang diterapkan dalam pengolahan dan pengembangan lahan pasang surut di Desa Banyuurip Kecamatan Tanjung lago Kabupaten banyuasin?

2. Berapa besar biaya produksi yang dikeluarkan dan pendapatan yang diterima petani pada usahatani padi di lahan pasang surut didesa Banyuurip Kecamatan Tanjung Lago Kabupaten Banyuasin?

3. Apakah usahatani padi di lahan pasang surut di Desa Banyuurip menguntungkan?

\section{PELAKSANAAN PENELITIAN}

\section{A. Ruang Lingkup Penelitian}

Penelitian dilaksanakan di Desa Banyuurip Kecamatan Tanjung Lago Kabupaten Banyuasin. Penentuan tempat penelitian dilakukan secara segaja (purposive) dengan pertimbangan bahwa daerah ini sebagian besar penduduknya berusahatani padi sawah pada lahan pasang surut, disamping itu daerah ini merupakan sentra produksi beras dan lahan pasang surut yang berpontensi untuk usahatani tanaman padi sawah. Pelaksanaan penelitian dilakukan pada bulan November 2017 Sampai Februari 2018

\section{B. Metode Penelitian dan penarikan Contoh}

Metode penelitian yang digunakan adalah metode survei dengan petani yang mengusahakan tanaman padi di lahan pasang surut di Desa Banyuurip Kecamatan Tanjung Lago Kabupaten Banyuasin sebagai satuan sampel. Metode penarikan contoh pada penelitian ini adalah contoh acak sederhana (Simple Random Sampling), dengan jumlah petani contoh sebanyak 30 petani yang berasal dari populasi sebanyak 359 petani yang berusahatani padi pada lahan pasang surut

\section{Metode Pengumpulan Data}

Data yang dikumpulkan adalah data primer dan data sekunder. Data Primer diperoleh melalui wawancara langsung dengan petani contoh yang menggunakan daftar pertanyaan yang telah disiapkan sebelumnya. Data yang dikumpulkan terdiri dari:

1. Luas lahan tanaman padi yang diusahakan.

2. Biaya produksi yang dikeluarkan oleh petani pada usahatani padi.

3. Produksi yang diperoleh dari usahatani padi.

4. Penerimaan dan pendapatan dan usahatani padi.

Sedangkan data sekunder diperoleh dan lembaga instansi yang terkait dengan penelitian.

\section{Metode Pengolahan Data}

Data yang diperoleh dari pelitian diolah secara tabulasi dilanjutkan dengan manganalisis secara matematis serta dijelaskan secara kualitatif dan kuantitatif.

Untuk menjawab permasalahan usahatani digunakan analisis matematis dengan rumusan sebagai berikut ;

1. Biaya Total $\mathrm{BT}=\mathrm{BTp}+\mathrm{BV}$. $\mathrm{BT}=$ Biaya Total $(\mathrm{Rp} / \mathrm{ha} / \mathrm{MT})$ 
$\mathrm{BTp}=$ Biaya Tetap $(\mathrm{Rp} / \mathrm{ha} / \mathrm{MT})$

$\mathrm{BV}=$ Biaya variable $(\mathrm{RP} / \mathrm{ha} / \mathrm{MT})$

2. Penerimaan $\mathrm{Pn}=\mathrm{Hj} \times \mathrm{Y}$

$\mathrm{Pn}=$ Penerimaan usahatani padi (Rp/ha/MT)

$\mathrm{Hj}=$ Harga jual gabah/padi kring panen $(\mathrm{Rp} / \mathrm{Kg})$

$\mathrm{Y}=$ Jumlah produksi gabah kering panen $(\mathrm{Rp} / \mathrm{ha} / \mathrm{MT})$

3. Pendapatan $\mathrm{Pd}=\mathrm{Pn}-\mathrm{BT}$.

$\mathrm{Pn}=$ Penerimaan usahatani padi (Rp/ha/MT)

$\mathrm{BT}=$ Biaya Total $(\mathrm{Rp} / \mathrm{ha} / \mathrm{MT})$

4. Kelayakan

Sedangkan untuk menjawab permasalahan kedua digunakan analisis $\mathrm{R} / \mathrm{C}$ dengan rumusan sebagai berikut :

$\mathrm{R} / \mathrm{C}=\frac{\text { Penerimaan }}{------------}$

$\mathrm{R} / \mathrm{C}>1$, Usaha yang dilaksanakan mengungtungkan dan layak untuk di usahakan.

$\mathrm{R} / \mathrm{C}=1$, Usaha yang dilaksanakan tidak menguntungkan dan tidak mengalami

kerugia, berada pada posisi break event point (BEP)

$\mathrm{R} / \mathrm{C}<1$, Usaha yang dilaksanakan mengalami kerugian dan tidak layak di usahakan

\section{HASIL DAN PEMBAHASAN}

\subsection{Karakteristik Lahan Pasaang surut}

Lahan pasang surut pada dasarnya merupakan lahan-lahan yang secara alami mempunyai satu atau lebih kendala sehingga butuh upaya ekstra agar dapat dijadikan lahan budidaya yang produktif untuk tanaman, ternak, atau ikan. Kendalah tersebut dapat berupa: [1] kesulitan dalam menyediakan air yang cukup untuk mendukung usaha tani yang produktif dan menguntungkan; [2] sifat kemasaman tanah yang tinggi ( $\mathrm{pH}$ rendah) sehingga butuh upaya untuk menetralisir kemasaman tanah tersebut; [3] dinamika pasang-surut genangan air yang sulit diprediksi sehingga dapat menyebabkan gagal tanam maupun gagal panen; [4] lahan terpengaruh oleh intrusi air laut; [5] terdapat lapisan pirit dangkal yang menjadi ancaman karena dapat meracuni sistem perakaran tanaman; [6] sangat miskin unsur hara sehingga membutuhkan dosis pemupukan yang lebih tinggi; dan/atau [7] tanah berbatu sehingga sulit diolah secara mekanis. Kondisi suboptimal ini dapat terjadi secara alami, akibat terkena dampak dari kegiatan manusia di dan/atau sekitar lokasi yang bersangkutan, atau akibat salah kelola pada periode sebelumnya.

\subsection{Strategi Pengembangan Teknologi Tepat Guna}

Selain teknologi yang secara langsung dibutuhkan oleh petani atau komponen masyarakat lainnya yang menggunakan lahan sebagai basis kegiatan produktifnya, teknologi untuk menghasilkan produk dan/atau sarana produksi juga patut untuk dikembangkan. Teknologi dimaksud termasuk teknologi untuk menghasilkan benih unggul; pupuk yang efektif, efisien, dan ekologis; bahan kimia atau organik dan (mikro)organisme untuk pengendalian hama dan patogen tanaman, ternak, dan ikan; hormon dan zat pengatur tumbuh; serta alat dan mesin budidaya dan pengolahan hasil pertanian. Khusus untuk pengelolaan lahan-lahan pasang surut, maka semua teknologi ini harus disesuaikan dengan kondisi lahan, agroklimat, kapasitas dan preferensi pengguna potensialnya, serta kondisi sosiokultural setempat.

Ada dua alur pokok yang saling komplementer dalam pengelolaan lahan pasang surut agar bisa dijadikan lahan pertanian yang produktif, yakni: [1] perbaikan sifat fisika, kimia, dan biologi tanah serta tata air agar lebih optimal; dan [2] peningkatan daya adaptasi tanaman, ternak, atau ikan terhadap karakteristik lahan dan kondisi agroklimat yang tidak optimal 
Secara umum ada empat pra-syarat untuk keberhasilan proses difusi teknologi, yakni: [1] Teknologi yang dikembangkan secara teknis relevan dengan kebutuhan pengguna; [2] Selain relevan secara teknis, teknologi yang ditawarkan harus sepadan dengan kapasitas absorpsi (calon) pengguna yang disasar; [3] Teknologi yang ditawarkan mampu bersaing dengan teknologi serupa yang tersedia di pasar; dan [4] Aplikasi teknologi yang ditawarkan akan lebih menguntungkan dibandingkan dengan praktek bisnis yang saat ini dilakukan.

\section{a. Perbaikan Sifat Fisika, Kimia, dan Biologi}

Seperti telah dijelaskan pada awal artikel ini, lahan suboptimal memiliki karakteristik sifat fisik, kimia, dan biologi yang beragam. Upaya perbaikan untuk mengelola lahan pasang surut menjadi optimal membutuhkan teknik pengelolaan yang tepat sesuai dengan karakteristiknya. Melalui penerapan iptek yang benar, maka lahan suboptimal dengan tingkat kesuburan alami yang rendah dapat dijadikan areal pertanian produktif.

Pengembangan lahan pasang surut untuk usaha pertanian umumnya dihadapkan dengan beberapa persoalan terkait sifat fisik, kimia dan biologi tanah, diantaranya kadar liat atau bahan organik tinggi, kemasaman tanah yang tinggi, keracunan $\mathrm{Fe}$ dan $\mathrm{Al}$, serta kahat unsur hara seperti N, P, K, Ca dan Mg.

Berbagai teknologi unggulan di lahan pasang surut yang telah dihasilkan oleh berbagai perguruan tinggi dan lembaga litbang diantaranya adalah penataan lahan, pengelolaan air, pengelolaan tanaman, pengelolaan bahan ameliorasi dan hara, serta pengendalian gulma.

Penggunaan ameliorant antara lain berupa kapur (kalsit, dolomit, dan kapur oksida), garam, sekam padi, abu serbuk kayu gergajian, biomasa gulma, dan limbah pertanian; sedangkan pengelolaan hara dengan cara pemberian pupuk hayati, pupuk $\mathrm{N}, \mathrm{P}$ dan $\mathrm{K}$, terbukti mampu meningkatkan hasil padi, palawija dan sayuran. Intensitas dan produktivitas yang rendah pada lahan pasang surut dapat ditingkatkan dengan penerapan teknologi pola tanam terpadu dengan pemilihan varietas padi dan palawija serta sayuran yang teruji (Alihamsyah et al., 2004).

Pemanfatan lahan pasang surut untuk pertanian menyebabkan perubahan sifat kimia dan biologi tanah. Penelitian Gofar (2007) di lahan rawa lebak Sumatera Selatan menunjukkan bahwa perbedaan tipe penggunaan lahan berpengaruh nyata terhadap penurunan $\mathrm{pH}$ tanah, kadar $\mathrm{C}$ organik, N-total, P-total dan populasi mikroba menguntungkan dalam tanah. Beberapa penyebab yang mengakibatkan perbedaan tersebut antara lain: [1] lama pengusahaan lahan, [2] intensitas pengolahan, jenis pupuk serta dosis pupuk yang digunakan, [3] jenis tanaman yang diusahakan, [4] aktivitas organisme tanah, dan [5] kondisi awal lahan yang diusahakan. Bahan organik merupakan penyangga biologis yang mempunyai fungsi dalam memperbaiki sifat fisik, kimia, dan biologi tanah sehingga dapat menyediakan unsur hara dalam jumlah berimbang bagi tanaman. Tanah dengan kandungan bahan organik yang tinggi akan hara.

Peningkatan produktivitas lahan suboptimal dapat dilakukan dengan pemanfaatan mikroba tanah, baik yang hidup bebas di dalam tanah maupun yang bersimbiosis dengan tanaman. Fitri dan Gofar (2010) melaporkan bahwa konsorsium bakteri endofitik pemacu tumbuh hasil isolasi dari jaringan tanaman padi dengan populasi $107 \mathrm{spk} \mathrm{mL}-1$ mampu meningkatkan hasil tanaman padi pada tanah asal pasang surut.

\section{b. Pengolahan Tanah dan air}

Usaha padi didesa Banyuurip dilakukan setahun satu kali dan merupakan 
komoditas utama dilahan pasang surut. Pengolahan lahan yang dianjurkan tergantung pada tipelogi tanah, tipe luapan air dan sistem usaha tani satu jenis tanaman atau lebih.

Desa Banyuurip tergolong tipologi lahan pontensial dengan tipe luapan air golongan B dan usahatani satu jenis tanaman penataan lahan dan tata air mikro pada petani dilakukan dengan sistem satu arah dengan sistem ini saluran tersier berfungsi tunggal sebagai saluran pemasukan dan saluran pengeluaran air. Dengan diterapkannya pengaturan air satu arah ini diharapkan tidak terjadi pencampuran air segar dengan air yang mengandung racun hasil pencucian sehingga kualitas air tetap terjaga.

Strategi pengendalian muka air ditujukan kepada aspek upaya penahanan muka air tanah agar selalu di atas lapisan pirit dan pencucian lahan melalui sistem drainase terkendali. Kondisi muka air yang diinginkan sangat tergantung kepada jenis tanaman, jenis tanah, dan kondisi hidrologis wilayah setempat (Imanudin dan Susanto, 2008). Permasalahan dalam budidaya tanaman non padi di lahan rawa adalah kelebihan air yang sangat mengganggu pertumbuhan awal tanaman. Sementara itu, kalau penanaman ditunda, maka akan terjadi kekurangan air pada fase generatif. Permasalahan status air ini dapat diatasi dengan membangun sistem drainase yang tepat (Imanudin dan Tambas, 2002).

\section{c. Varietas.}

Varietas merupakan salah satu komponen penting dalam sistem produksi alam upaya peningkatan produksi padi terutama dilahan pasang surut varietas yang memiliki potensi hasil tinggi. Varietas padi yang diharapkan adalah padi berpotensi hasil tinggi berumur pendek, tahan hama dan penyakit, toleran terhadap lingkungan dan berkualitas lebih baik. Di desa Banyuurip varietas yang banyak ditanam adalah Ciherang, IR42 dan IR64 ketiga varitas unggul nasional ini telah beradaptasi dengan lahan pasang surut dan mempunyai produkvitas yang cukup tinggi.

\section{c. Sistem Tanam}

Sistem tanam yang banyak dilakukan petani di desa Bayuurip adalah sistem tabur benih langsung, hal ini disebabkan menghemat tenaga kerja dengan sistem tabela mempunyai kelemahan benih padi yang disebar tumbuh kurang serempak penyemaian tanaman mati menyebabkan tanaman tumbuh terlambat dan tidak seragam akibatnya waktu keluar malah tidak serempak.

Pada sestem Tanam Benih Langsung (TABELA) proses pertumbuhan anakan tumbuh awal dan jumlah anakan yang dihasilkan lebih banyak dibandingfkan denagn sistem tanam pindah anakan merupakan komponen hasil padi yang menentukan jumlah malai yang terbentuk namun kemampuan padi membentuk anakan pada sistem tabela perlu diatur dan diantisipasi.

beberapa komponen utama seperti modernisasi cara tanam dengan menggunakan alat tanam amator yang ditarik dengan traktor dan dimodifikasi sesuai jarak tanam tegel maupun legowo dan bisa disesuaikan dengan kondisi lapisan tanah yang dalam maupun dangkal, sehingga memudahkan dan menghemat waktu tanam.

\section{d. Pemupukan.}

Salah satu ciri spesifik lahan pasang surut adalah tingginya tingkat keragaman kesuburan tanah sekalipun dalam satu petakan sawah.untuk mendapatkan dosis pupuk yang tepat pada tingkat keragaman yang tinggi merupkan suatu masalah tersendiri pemberian pupuk $\mathrm{N}$ diberikan tiga kali yaitu pada saat tanam.umur 14 28 hari atau stadia vegetatif dan pada saat umur tanaman 50 hari atau masa primodia, sedangkan pupuk $\mathrm{P}$ dan $\mathrm{K}$ diberikan pada saat tanam. Jika tidak tersedia maka pengisian biji akan terganggu dan bobot 
dan bobot biji berkurang. Pemupukan yang tepat dan _eco friendly_ melalui bioremediasi dan ameliorasi.

Penambahan unsur hara anorganik pada paket teknologi tepat guna dilakukan berdasarkan status hara tanah dan kebutuhan tanaman agar kondisi hara dalam tanah berimbang atau sesuai target produktivitas tanaman yang akan dicapai. Penentuan takaran N, P dan K berdasarkan uji tanah dapat menggunakan alat Perangkat Uji Tanah Rawa (PUTR), sedangkan pemberian pupuk $\mathrm{N}$ susulan menggunakan Bagan Warna Daun (BWD).

Untuk mendukung keberlanjutan sumber daya lahan, paket teknologi RAISA dilengkapi dengan aplikasi pupuk hayati yang adaptif dengan tanah masam lahan rawa dan mampu meningkatkan produktivitas tanaman yaitu Biotara. Keunggulan dari pupuk hayati biotara adalah dapat mengikat $\mathrm{N}$, meningkatkan ketersediaan hara $\mathrm{P}$ tanah, mendekomposisi sisa-sisa organik dan memacu pertumbuhan.

Selain itu pupuk hayati biotara juga dapat meningkatkan efisiensi pemupukan $\mathrm{N}$ dan $\mathrm{P}$ sampai dengan $30 \%$ dan meningkatkan hasil padi sampai dengan $20 \%$ di lahan rawa. Aplikasi pembenah tanah atau amelioran juga dilakukan untuk memperbaiki sifat fisik, kimia dan biologi tanah sehingga kondisi tanah menjadi lebih sesuai (favorable) bagi tanaman. Beberapa bahan amelioran, yang dapat digunakan antara lain bahan organik, pupuk organik, kompos, gypsum, fosfat alam, biochar dan kapur.

Dalam rangka pemulihan tanah yang sudah mengalami degradasi baik fisik, kimia maupun biologi, komponen paket teknologi tepat guna juga menyertakan kegiatan remediasi. Proses ini dapat meningkatkan $\mathrm{pH}$, retensi air dan hara, aktivitas biota tanah dan mengurangi keracunan dan pencemaran. Pada kegiatan kali ini digunakan remediasi hayati berupa pemanfaatan gulma yang banyak ditemukan di sekitar lahan yaitu purun tikus.

\section{e. Teknik Pemeliharaan Tanaman}

Pemeliharaan yang dilakukan pada tanaman padi pasang surut di Desa Banyuurip berupa penyiangan dan pengendalian hama penyakit gulma merupakan masalah penting karena bersaing denga tanaman padi dalam hal tempat, cahaya, unsur hara, dan air. Pemeliharaan tanaman dengan dengan cara manual yaitu dengan cangkul, sabit atau dengan tangan pada sat tanam erumur 3 - 4 minggu dan 7 - 8 minggu sedangkan dengan cara kimiawi menggunakan herbisida pra tanam. penyiangan dilakukan 1-2 kali tergantung kepadatan gulma.

Faktor yang tidak kalah penting adalah pengendalian hama dan penyakit pada padi umumnya erat hubungannya dengan kondisi hara tanaman umumnya serangan penyakit musim kemarau.penyakit yang sering ditemukan pada usaha tani padi yaitu busuk pelepah batang. Pengendalian penyakit tanaman padi lahan pasang surut dilakukan dengan pendekatan perbaikan sifat fisik dan kimia tanah.

Hama yang sering menyerang tanaman padi di desa Banyuurip adalah tikus, wereng, coklat, walang sangit, penggerek batang padi, serangan hama tikus umumnya sebebakan oleh bertanam padi tidak serempak, tanaman bokor tunggul/pohon yang belum dibersihkan. Upaya pengendalian serangan hama tikus dilakukan dengan cara sanitasi dan gropyokan, penggunaan rotentisida, pengemposan sap belerang dan pengamatan rutin. Pengendalian hama saat ini dilakukan dengan menanam varietas tahan dan pengendalian apabila telah melampaui ambang batas toleransi dengan menggunakan bahan kimia.

Pengendalian hama penyakit diarahkan pada strategi pengelolaan hama 
penyakit terpadu (PHT). 4. Pemanfaatan varietas unggul baru potensi hasil tinggi spesifik ekosistem varietas unggul merupakan salah satu komponen utama teknologi yang terbukti mampu meningkatkan produktivitas. varietas unggul padi spesifik lahan pasang surut diantaranya Inpara 1, Inpara 2, Inpara 3, Inpara 6, Inpara 7, Inpara 8 Agritan dan Inpara 9 Agritan.

\section{f. Panen dan Pasca Panen}

Umumnya di Desa Banyuurip Kecamatan Tanjung Lago Kabupaten Banyuasin, Padi siap panen: $95 \%$ butir sudah menguning yaitu 33-36 hari setelah berbunga, bagian bawah malai masih terdapat sedikit gabah hijau, kadar air gabah 21-26\%, butir hijau rendah. Cara panen yang dilakukan oleh petani Desa Banyuurip Kecamatan Tanjung Lago Kabupaten Banyuasin sawah dikeringkan 7-10 hari sebelum panen, dengan menggunakan sabit tajam untuk memotong pangkal batang, simpan hasil panen di suatu wadah atau tempat yang dialasi.

Penanganan pasca panen padi yang dilakukan petani di Desa Banyuaurip kecamatan Tanjung Lago Kabupaten Banyuasin dengan menggunakan Power threser. Keuntungan power threser adalah meningkatkan kapasitas perontokan gabah yang dihasilkan bersih dan memudahkan proses berikutnya yaitu mengeringkan. Pengeringan gabah dapat dilakukan dengan penjemuran langsung dengan dialasi terpal atau kalau ada dengan mesin pengiring box dryer pengeringan /penjemuran gabah selama 3 - 4 hari selama 3 jam perhari sampai kadar air 14 persen.

Jika menggunakan mesin pengering gabah dapat dikeringkan dalamjangka waktu 9 jam setelah kering gabah dapat digiling atau disimpan dalam karung bersih

\subsection{Tantangan Pengelolaan Lahan Pasang Surut}

Pengelolaan lahan pasang surut masih banyak menghadapi permasalahan. Selain aspek fisik lahan seperti yang telah diungkapkan sebelumnya, permasalahan non fisik antara lain rendahnya minat dan kemampuan enterpreneurship petani, lemahnya sistem kelembagaan untuk memfasilitasi dan melindungi usahatani masyarakat, dan aplikasi teknologi yang rendah terutama karena terkendala oleh kapasitas finansial petani yang tidak memadai.

Dalam pengelolaan sumberdaya air, seringkali terjadi benturan kepentingan dalam menentukan prioritas pemanfaatan air di lapangan, antara kepentingan transportasi, pertanian, atau kegiatan lainnya. Dari aspek budidaya, kendala yang dihadapi adalah: [1] persiapan lahan, pemakaian benih varitas unggul, penanaman (waktu tanam, cara tanam), pemeliharaan,pemupukan, pengendalian

hama, penyakit tanaman dan gulma yang belum dilakukan dengan baik; [2] belum dilaksanakan integrasi dengan budidaya ternak (itik, kerbau) dan ikan sehingga produktivitas lahan suboptimal masih rendah; [3] penanganan panen dan pasca panen belum dilakukan dengan baik dan efisien sehingga persentase kehilangan masih tinggi.

Aksesibilitas yang rendah akibat prasarana transportasi yang belum tersedia atau dalam kondisi yang buruk juga menjadi tantangan dalam pengelolaan lahan pasang surut Terbatasnya aksesibilitas menyebabkan biaya angkut hasil produksi maupun sarana produksi relatif mahal. Kurangnya infrastruktur penunjang dalam pembangunan pertanian di lahan suboptimal akan berdampak pada rendahnya produktivitas dan kualitas produk serta sulitnya pemasaran.

Faktor kendala lain adalah keterbatasan tenaga kerja, karena umumnya kepadatan penduduk yang bermukim di lahan pasang surut sangat rendah. Akibatnya, pendapatan penduduk dari pengusahaan komoditi pangan rendah, dan pada beberapa daerah hal tersebut 
dapat mendorong terjadinya alih fungsi lahan tanaman pangan ke penggunaan lain, diantaranya untuk perkebunan terutama tanaman padi. Daerah rawa memiliki potensi produk sampingan limbah pertanian yang potensial. Limbah pertanian yang dominan adalah dari tanaman padi, rumput rawa, perkebunan sawit, dan kotoran hewan yang sampai saat ini masih belum dimanfaatkan. Limbah ini berpotensi dijadikan pupuk kompos sehingga ketergantungan menggunakan pupuk buatan dapat dikurangi atau dimanfaatkan sebagai sumber energi untuk memenuhi kebutuhan rumah tangga.

Pengembangan teknologi pengolahan merupakan salah satu alternatif penganekaragaman produk sebagai penunjang agroindustri yang sesuai untuk tingkat pedesaan dan meningkatkan nilai tambah komoditas di lahan suboptimal. Dengan lebih beragamnya produk olahan diharapkan dapat mendukung program ketahanan pangan. Dampak pengembangan agroindustri di pedesaan antara lain dapat mendorong tumbuhnya usaha-usaha di bidang pengolahan pangan, bengkel peralatan dan meningkatkan status gizi masyarakat (Antalina dan Umar, 2009).

\subsection{Biaya Produksi}

Seluruh biaya yang dikeluarkan oleh petani dalam proses produksi serta membawanya menjadi produk, termasuk didalamnya barang yang dibeli dan jasa yang dibayar didalam maupun diluar usahatani. Biaya produksi usaha tani padi dikelompokkan sebagai berikut:

a. Biaya tetap yaitu berupa biaya penyusutan alat seperti, cangkul, parang, karung, arit dan hand sprayer.

b. Biaya variabel atau biaya tidak tetap, seperti pembelian bibit, pupuk, obatobatan dan upah tenaga kerja.

Adapun rata-rata biaya produksi

yang dikeluarkan petani contoh dalam usaha tani padi dapat dilihat pada tabel

6.

Tabel 6. Rata-rata Biaya Produksi

Petani Contoh usahatani padi, tahun 2018

\begin{tabular}{|c|c|c|}
\hline No. & $\begin{array}{c}\text { Jenis } \\
\text { Biaya }\end{array}$ & $\begin{array}{c}\text { Jumlah } \\
(\mathbf{R p})\end{array}$ \\
\hline 1. & Biaya & 3.835 .333 \\
2. & Tetap & 12.045 .573 \\
& Biaya & \\
& Variabel & \\
\hline \multicolumn{2}{|c|}{ Jumlah } & $\mathbf{1 5 . 8 8 0 . 9 0 7}$ \\
\hline
\end{tabular}

Berdasarkan Tabel 6 di atas menunjukkan bahwa rata-rata biaya produksi yang dikeluarkan petani contoh dalam usahatani padi lahan pasang surut di Desa Banyu Urip adalah sebesar Rp. 3.835.333,- Biaya yang terbesar adalah biaya variabel yaitu rata-rata sebesar Rp. 12.045.573,- yang terdiri dari pembelian bibit, pupuk, obat-obatan dan upah tenaga kerja, Untuk jelasnya biaya produksi yang dikeluarkan masing-masing petani contoh dapat dilihat pada Lampiran 9.

\subsection{Penerimaan Petani padi lahan pasang surut}

Penerimaan merupakan pendapatan kotor berupa nilai produksi yang diperoleh dari usahatani padi lahan pasang surut. Penerimaan dinyatakan dalam bentuk hasil kali antara produksi fisik yang diperoleh dan suatu usaha dikalikan dengan harga produksi persatuan fisik. Hasil perhitungan penerimaan usahatani bengkuang disajikan pada Tabel 7 berikut:

Tabel 7. Rata-rata Penerimaan Usaha tani padi lahan pasang surut diBanyuurip tahun 2018

\begin{tabular}{|c|c|c|}
\hline No & U r a i a n & $\begin{array}{c}\text { Jumlah } \\
(\mathbf{R p})\end{array}$ \\
\hline 1. & Produksi & 5.285 \\
\hline
\end{tabular}




\begin{tabular}{|c|l|r|}
\hline 2. & $\begin{array}{l}\text { (Kg/LG/MT) } \\
\text { Harga }\end{array}$ & 5.000 \\
(Rp/kg) & $\begin{array}{l}\text { Penerimaan } \\
(\mathrm{Rp} / \mathrm{LG} / \mathrm{MT})\end{array}$ & 26.425 .000 \\
\hline
\end{tabular}

Berdasarkan Tabel 7 menunjukkan bahwa rata-rata penerimaan petani contoh dalam usahatani padi lahan pasang surut adalah sebesar RP. 26.425.000,- yang merupakan hasil kali dari penjualan padi yang dijual dengan harga Rp. 5.000,- per kilogram. Adapun penerimaan masing-masing petani contoh dapat dilihat pada lampiran 8 .

\subsection{Pendapatan dan Keuntungan Usaha tani Padi}

Penerimaan setelah dikurangi biaya produksi akan diperoleh nilai pendapatan. Secara rinci pendapatan usahatani padi di lahan pasang surut pada petani contoh dapat dilihat pada Tabel 8.

Tabel 8. Rata-rata Pendapatan Usahatani padi di Desa Banyuurip tahun 2018.

\begin{tabular}{|c|c|c|}
\hline $\mathbf{N}$ & U r a i an & Nilai (Rp) \\
$\mathbf{o}$ & & \\
\hline 1 & Penerimaan & 26.425 .000$, \\
2 & Biaya Produksi & 15.880 .907$, \\
3 & Pendapatan & 10.544 .093 \\
4 & R/C & 1.66 \\
. & & \\
\hline
\end{tabular}

Berdasarkan Tabel 8 menunjukkan bahwa rata-rata pendapatan petani contoh dalam usahatani padi lahan pasang surut di Desa Banyu Urip adalah sebesar Rp. 7.974.093,-.R/C ratio usahatani padi sebesar 1,88. Artinya setiap Rp 1 yang di keluarkan petani untulk proses produksi maka petani mendapatkan keuntungan sebesar 1,88. hal ini menunjukkan bahwa usahatani padi di lahan pasang surut layak untuk di lanjutkan ataupun dapat member keuntungan kepada petani sebesar 1,88. Adapun perincian pendapatan masingmasing petani contoh dapat dilihat pada Lampiran 8.

\section{KESIMPULAN DAN SARAN}

\section{A. Kesimpulan}

1. Dua pendekatan yang dapat secara paralel dan interaktif dilakukan adalah [1] optimalisasi sifat fisik, kimia, dan (mikro)biologi tanah yang dibarengi dengan optimalisasi pengelolaan sumberdaya air agar efektif dan lebih efisien; dan [2] seleksi jenis komoditas yang sesuai dan pengembangan varietas yang adaptif secara spesifik untuk masing-masing karakteristik lahan suboptimal. Untuk mewujudkan keberlanjutan pengelolaan lahan suboptimal, maka semua upaya teknis dan teknologis yang dilakukan harus pula mempertimbangkan kemungkinan dampak ekologisnya, kesesuaian sosiokultural dengan masyarakat lokal, selain tentunya menguntungkan secara ekonomi bagi petani sebagai pelaku utamanya. Lahan suboptimal membutuhkan lebih banyak intervensi teknologi agar dapat dijadikan lahan pertanian yang produktif. Upaya ini selain mahal secara ekonomi, sering juga beresiko tinggi bagi lingkungan. Mudah untuk dipahami bahwa tidak seluruh bentang lahan pasang surutl dapat dan perlu dimanfaatkan untuk kepentingan ekonomi. Dengan demikian maka tidak semua jengkal lahan suboptimal harus digunakan sebagai lahan produksi; sebagian perlu tetap diperuntukan bagi kepentingan konservasi.

2. Rata rata biaya produksi usahatani padi pasang surut di desa Banyu urip adalah Rp.15.880.907 perluas garapan permusim tanam. Rata rata pendapatan yang diterima oleh petani contoh sebesar Rp.10.544.093,dan penerimaan diperoleh sebesar Rp. 26.425.000,- luas garapan permusim tanam.

3. R/C usahatani padi sebesar 1,88 . Artinya setiap $\mathrm{Rp} 1$ yang di keluarkan petani untulk proses 
produksi maka petani mendapatkan keuntungan sebesar 1,66. hal ini menunjukkan bahwa usahatani padi di lahan pasang surut layak untuk di lanjutkan ataupun dapat member keuntungan kepada petani sebesar 1,88 .

\section{B. Saran}

1. Padi merupakan tanaman yang sangat dibutuhkan untuk makanan pokok sehari hari bagi masyarakat,diharapkan petani dapat membuat perencanaan penanaman yang tepat dan diusahakan secara intensif sehingga produksi dapat optimal dan memenuhi kebutuhan masyarakat.

2. Untuk meningkatkan hasil produksi petani harus mampu menerapkan teknologi tepat guna yang mana dalam pelaksanaan membutuhkan peran serta dan bimbingan dari penyuluh pertanian.

\section{DAFTAR PUSTAKA}

Alihamsyah, T. 2004. Potensi dan pendayagunaan lahan rawa untuk peningkatan produksi padi. Ekonomi Padi dan Beras Indonesia. Dalam F. Karino, Efendi dan AM. Fagi (Penyunting). Badan Litbang Pertanian, Jakarta.

Antalina, SS. dan S. Umar. 2009. Teknologi pengolahan komoditas unggulan mendukung pengembangan agroindustry di lahan lebak. Prosiding Seminar Nasional Serealia. ISBN: 978979-8940-27-9.

Edgerton, D. 2006. The Shock of the Old: Technology and Global History Since 1900. Profile Books Ltd, London.

Endrizal dan B. Julistia. 2009. Pengembangan dan peningkatan produktivitas padi pada rawa lebak melalui pendekatan pengelolaan tanaman terpadu padi di Provinsi Jambi. Prosiding Seminar Nasional Padi, Hal.800-814.

Endrizal dan Jumakir. 2009. Produktivitas beberapa VUB padi rawa lebak mendukung desa mandiri pangan Kabupaten Batanghari. Balai Pengkajian Teknologi Pertanian Jambi.

Fitri, SNA. and N. Gofar. 2010. Increasing of rice yield by using growth promoting endophytic bacteria from swamp land. J. Tropical Soils. 15(2): 271-276.

Gofar, N. 2007. Keragaman beberapa sifat kimia dan biologi tanah pada berbagai tipe penggunaan lahan rawa lebak. Agritrop 26(2): 92-96. 